\title{
A Relationship among Adjustment, Life Style and Life Satisfaction of Educated Unemployed Youth
}

\author{
Mr. Rajendrakumar Muljibhai Parmar ${ }^{1 *}$
}

\section{ABSTRACT}

The main aim of the present study is to find out difference in level of adjustment, life style and life satisfaction of educated unemployed people. Second purpose is to find out difference in level of adjustment, life style and life satisfaction of with male and female people. Third aim is to find out difference in level of adjustment, life style and life satisfaction among rural and urban people. Forth intended is to find out difference in level of adjustment, life style and life satisfaction among different ages of people. Fifth purpose is to find out difference in level of adjustment, life style and life satisfaction of with its interaction effect on male and female, rural and urban and different ages of people.

The sample for the study comprised of 480 randomly selected out of 500 samples. The Adjustment Neurotism Dimensional Inventory, The questionnaire developed by R N Singh and Mahesh Bhargava. This inventory consists 105 items in three response alternatives and measures seven dimensions-Self-Esteem-Self Inferiority, Happiness-Depression, calmness-anxiety, neutrality obsessiveness, independence-dependence, feeling of being healthy-hypochondria sis, innocence-guilt feeling. It can be used on both the sexes from age group 17 to 60 years. Norms are available in form of Mean \& S.D. and Stenine Norms and life satisfaction questionnaire developed by Q G Alam\& R Shrivastva. It contains 69 Yes/No type items which yield a total score covering six areas — health, personal, economic, marital, social and job, Standardized on 875 adults aging between 18 to 40 years. Life Style Scale developed by S. K. Bawa and S. Kaur, the scale consists 60 items into 6 Dimension like Health Conscious Life Style, Academic Oriented Life Style, Career Oriented Life Style, Socially Oriented Life Style, Trend Seeking Life Style, and Family Oriented Life Style. Data analysis of questionnaire and demographic details were subjected through SPSS for t test, Interaction Effect and Correlation.

Keywords: Educated Unemployed Youth, Adjustment, Life Style and Life Satisfaction

\footnotetext{
${ }^{1}$ PhD Scholar, Department of Psychology, Sardar Patel University, Vallabh Vidya Nagar, Anand, India *Responding Author

(C) 2016 R Parmar; licensee IJIP. This is an Open Access Research distributed under the terms of the Creative Commons Attribution License (http://creativecommons.org/licenses/by/2.0), which permits unrestricted use, distribution, and reproduction in any Medium, provided the original work is properly cited.
} 


\section{A Relationship among Adjustment, Life Style and Life Satisfaction of Educated Unemployed Youth}

Mani is Unique and Excellence Creation of Nature. Nature has Gifted Intelligent, Thinking and Feeling to Mankind. If the Intimation between Nature and Mankind, Most of Today's Problems Become Light but Unfortunately Today's Man is Constantly Going Away From the Nature. The Reason being the Constantly Increasing Needs and Confecting attempt to fulfill these Needs; Every Men in the Presents Competitive age is involved in the Ambition to get more and more than others.

Consequently the incomplete expectation cause to mental problems, beside the most important matter is the striking desire to make adjustment with environment, the perfect adjustment with environment indicators the height of happiness. To make life meaningful, the individual has to make constant attempt to make in every field of life and in every stage of life. In making continuous attempt to adjust in the constantly changing environment, the individual has changed him or herself, after change in his or her environment. Adjusted persona possessed balanced personality and good mental health and then they feel satisfied with life.

There have been several studies in past that have paid attention on unemployment in various concepts and in various perspectives in abroad and in India but researchers laid vary little focus on psychological perspectives of unemployment. The fundamental assumption is that, there are unemployed people facing psychological problems like adjustment, life style, and decrease life satisfaction level of unemployed people. Now, capacity to tolerate these psychological problems from person to person is vary but till they have to face them because they are unemployed. Here, in this research main focus given to age and gender and location of Gujarat state's some cities.

\section{Unemployment}

Almost every day we read in newspapers about Youth/farmers committing suicide due to a high level of indebtedness, lack of job/farm and unemployment. There was a very touching story about a young man who lost his job due to the global meltdown. He did not have the heart to tell his family, friends or neighbours about the sad development. He would therefore, leave his home every day at the normal time in the morning with his brief case, spend the day in a garden and return in the evening.

There are an increasing number of young patients visiting psychiatrists for clinical depression caused by unemployment. In recent times, many college graduates have volunteered to work absolutely free in private companies. Their objective, in an absence of a paying job, it is to get some experience and add to their resumes so that when opportunities of paying jobs arise, they have a better chance than others.

\section{There is basic Psychological Impact on Unemployment}

Youth unemployment is an area of very serious concern in India. There is some Psychological Impact on Unemployment, Adjustment, Anger, Anxiety, Avoid Social Participation, Blaming 


\section{A Relationship among Adjustment, Life Style and Life Satisfaction of Educated Unemployed Youth}

Themselves, and Cardiovascular Decease Increase, Crime Rate Increasing, Depression, Effect on Health, Emotional Problem, Decrease Family Support, Guilt Feeling, Helplessness and Isolation from the Society, Lack of Self Esteem and Confidence, Less Interesting, Life Satisfaction Level Decrease, Loss of Enthusiasm and Willpower Issues, Loss of Identity, Loss of Skill, Mental Health Problem, Positive Attitude decrease, Relationship Problem with others, Sleep Disorder, Smoking Behaviour Increase, Social Support decrease, Stress, Suicides, Tension and etc.

\section{Adjustment}

Adjustment is a continuous process of action in the life of a human being or an organism with a definite purpose of meeting the needs of the self the needs of the environment and the needs of the culture or society the ultimate and of the process of action of the adjustment is successful survival. The end result may be survival or extermination a continuous close watch on the life of an organism or a human being may bring out many happy and unhappy events which are based upon the struggle for successful survival. Man is an interdependent creature, always expecting the help and the cooperation from other human beings and the culture or society in which he livers, for the fulfilment of his basic needs and also maker's inevitable demands from them.

Laurence Shaffer "Adjustment is the process by which a living organism maintains balance between his needs and the circumstances that influence the satisfaction of his needs"

Adjustment as a major importance for psychologists, teachers and parents; to analyses the process we should study the development of an individual longitudinally from his birth onwards. The child, at the time of his birth, is absolutely dependent on other for the satisfaction of this need, but gradually with the age he learns to control his needs. His adjustment largely depends on his interaction with the external environment in which he lives. When the child is here, the world, for him, is a big buzzing, blooming confusion. He cannot differentiate among the various objects of his environment but as he matures he comes to learn to articulate the details of his environment through the process of sensation, perception and conception. The child in his infancy can respond and think about only concrete objects of his environment. The process of abstraction comes afterwards. The young children lack the capacity of self-control of the instinctive impulses. Anything which appears to their senses bright they try to take hold of it. Their development is purely on instinctive level. The nature of adjective process is decided by a number of factors, particularly, internal needs and external demands of the child.

\section{Life satisfaction}

Life satisfaction is a multi-dimensional concept. As noted above, the notion of quality of life and the consideration of several areas of life broaden the narrower focus on income and material conditions which prevails in other approaches. Multi-dimensionality not only requires the description of several life domains, but emphasizes the interplay between domains as this contributes to quality of life. 


\section{A Relationship among Adjustment, Life Style and Life Satisfaction of Educated Unemployed Youth}

Quality of life satisfaction is measured by objective as well as subjective indicators. Subjective and attitudinal perceptions are of particular relevance in identifying individual goals and orientations. Individual perceptions and evaluations are most valuable when these subjective evaluations are linked to objective living conditions. Applying both ways of measuring quality of life gives a more complete picture.

\section{Conceptualizing Lifestyle Psychology}

There are people who strictly deprive themselves of each and every eatable, drinkable, and smokable which has in any way acquired a shady reputation. They pay this price for health. And health is all they get for it. -Mark Twain

At the end of this chapter you will: have a working definition of lifestyle diseases and lifestyle behaviours:-

- $\quad$ Understand the development of a lifestyle model of disease

- $\quad$ Be aware of the problems with measuring lifestyle behaviours

- $\quad$ Recognize the multiple influences on lifestyle choice.

The decision to write a text on lifestyle psychology reflects an appreciation of the importance of the government and policy makers' use of the term lifestyle to refer to diseases where behaviour plays a part in the a ethology of the condition. In a speech in 2006, the then prime minister of Great Britain, Tony Blair, called for 'lifestyle change' to relieve the pressure on the National Health Service. The prime minister suggested that 'failure to address bad lifestyles was putting an "increasing strain" on the health service'. The centrality of the message, the role of lifestyle in health, and the role of psychology in promoting and improving lifestyle will form the focus of this text.

\section{RESEARCH METHODOLOGY}

\section{Problem statement:}

“A study of Adjustment, Life Style, and Life Satisfaction among Educated Unemployed Youth”

\section{The Importance for the present study}

Through this study researcher want to know about how many people facing problem of unemployment and what they are in front of them during unemployment condition. What kind of struggle they have to do get employment, what kind of psychological problems they faced, like for example adjustment, anger, anxiety, depressions, emotional problems, crime rate increasing, mental health problems, stress, suicides, blaming themselves, cardiovascular decease increasing, family support decreasing, isolation from the society, life satisfaction, loss of identity, loss of skills, relationship maintain problems, decrease social support, smoking behaviour increasing etc., all kind of problem faced by unemployment people. 


\section{A Relationship among Adjustment, Life Style and Life Satisfaction of Educated Unemployed Youth}

This study helps to systematize employment in rural and rural area. The problem of unemployment among the educated is not a new one. Present study help to know how and what kind of changes an unemployed person has made so that they can get easily employment. There is a considerable proof that suicidal tendencies are seen more in unemployed people so that what psychologist, sociologist and economist helps to reduce the suicidal tendency. There are an increasing number of young patients visiting psychiatrists for clinical depression caused by unemployment so how psychologist, sociologist, and economist facilitate unemployed people so that we can decrease psychological problem in unemployed youth.

There have been several studies in past that have paid attention on unemployment in various concepts and in various perspectives in abroad but researchers laid vary little focus on psychological perspectives of unemployment.

\section{Objectives of Research}

1. To study of Adjustment, Life satisfaction and Life Style of male and female people.

2. To study of Adjustment, Life satisfaction and Life Style of among rural and urban people.

3. To study of Adjustment, Life satisfaction and Life Style of among different ages of people.

4. To study interaction effect of Adjustment, Life satisfaction and Life Style among Gender, Live in Area and among different age's people.

\begin{tabular}{|c|c|c|c|c|}
\hline Sr. No & Name of Variable & $\begin{array}{l}\text { Nature of } \\
\text { Variable }\end{array}$ & $\begin{array}{l}\text { Levels of } \\
\text { Variable }\end{array}$ & Level of Name of Variable \\
\hline \multirow{2}{*}{1} & \multirow{2}{*}{ Types of Gender } & \multirow{2}{*}{$\begin{array}{l}\text { Independent } \\
\text { Variables }\end{array}$} & \multirow{2}{*}{2} & Male \\
\hline & & & & Female \\
\hline \multirow{3}{*}{2} & \multirow{3}{*}{ Age } & \multirow{3}{*}{$\begin{array}{l}\text { Independent } \\
\text { Variables }\end{array}$} & \multirow{3}{*}{3} & 18 to 25 Year \\
\hline & & & & 26 to 33 Year \\
\hline & & & & 34 and Above \\
\hline \multirow{2}{*}{3} & \multirow{2}{*}{ Live in Area } & \multirow{2}{*}{$\begin{array}{l}\text { Independent } \\
\text { Variables }\end{array}$} & \multirow{2}{*}{2} & Urban \\
\hline & & & & Rural \\
\hline 4 & Adjustment & $\begin{array}{l}\text { Dependent } \\
\text { Variables }\end{array}$ & 7 & $\begin{array}{l}\text { Scores of Various Levels of } \\
\text { Adjustment }\end{array}$ \\
\hline 5 & Life Style & $\begin{array}{l}\text { Dependent } \\
\text { Variables }\end{array}$ & 6 & $\begin{array}{l}\text { Scores of Various Levels of } \\
\text { Life Style }\end{array}$ \\
\hline 6 & Life Satisfaction & $\begin{array}{l}\text { Dependent } \\
\text { Variables }\end{array}$ & 6 & $\begin{array}{l}\text { Scores of Various Levels of } \\
\text { Life Satisfaction }\end{array}$ \\
\hline
\end{tabular}

\section{Control Variable:}

Note that in an experiment there may be many additional variables beyond the manipulated independent variable and the measured dependent variables. It is critical in experiments that these variables do not vary and hence bias or otherwise distort the results. There is a struggle between controls vs. authenticity in managing this. 


\section{A Relationship among Adjustment, Life Style and Life Satisfaction of Educated Unemployed Youth}

1. Normal people are taken in research.

2. $\quad$ All age was taken as sample between 18 to 40 years.

3. Only three cities included for this research.

4. $\quad$ Part time job working people was not included

\section{Hypothesis}

1. There is no significant difference between level of adjustment in male and female.

2. There is no significant difference between level of adjustment in Urban and Rural People.

3. There is no significant difference between levels of adjustment among different ages of people.

4. There is no significant difference between level of Life Satisfaction in male and female.

5. There is no significant difference between level of Satisfaction in Urban and Rural People.

6. There is no significant difference between levels of Life Satisfaction among different ages of people.

7. There is no significant difference between level of Life Style in male and female.

8. There is no significant difference between level of Life Style in Urban and Rural People.

9. There is no significant difference between levels of Life Style among different ages of people.

10. There is no significant difference between level of adjustment in male and female \& among different ages of people.

11. There is no significant difference between level of adjustment in male and female \& Urban and Rural People.

12. There is no significant difference between levels of adjustment among different ages of people \& Urban and Rural People.

13. There is no significant difference between level of adjustment in male and female with \& different ages of people in Urban and Rural area.

14. There is no significant difference between level of Life Satisfaction in male and female \& among different ages of people.

15. There is no significant difference between level of Life Satisfaction in male and female \& Urban and Rural People.

16. There is no significant difference between levels of Life Satisfaction among different ages of people \& Urban and Rural People.

17. There is no significant difference between level of Life Satisfaction in male and female with \& different ages of people in Urban and Rural area.

18. There is no significant difference between level of Life Style in male and female \& among different ages of people.

19. There is no significant difference between level of Life Style in male and female \& Urban and Rural People.

20. There is no significant difference between levels of Life Style among different ages of people \& Urban and Rural People.

21. There is no significant difference between level of Life Style in male and female with \& different ages of people in Urban and Rural area. 


\section{A Relationship among Adjustment, Life Style and Life Satisfaction of Educated Unemployed Youth}

\section{Population \& Sample of the study}

The researcher was collected data from the Vadodara, Ahmadabad, Anand cities of Gujarat state. Data was collected from the Employment Exchange, face to face meet to the subject, NGO, recruitment fair, ITI Job Fair, etc. Places. For these researches 480 youths of above mention cities were chosen, whose age between 18 years to 40 years was taken and the sample was randomly selected, which are educated unemployed. The data was collected personally. The sample was drawn from three categories. 1:- Male \& Female, 2:- Urban and Rural Area and, 3:Age differences Among Unemployed.

\section{Research Tools}

\section{Personal Data Sheet}

To obtain the personal details of the subjects, researcher had prepared personal data sheet. The data sheet includes the information about name of the subject, age, sex, types of family, marital status, total income, time of unemployment, religious, total family members, job, caste, educational qualification, contact number and many information was ask.

\section{Adjustment Neurotism Dimensional Inventory}

The questionnaire developed by R N Singh and Mahesh Bhargava. This inventory consists 105 items in three response alternatives and measures seven dimensions-self-esteem-self inferiority, happiness-depression, calmness-anxiety, neutrality obsessiveness, independence-dependence, feeling of being healthy-hypochondriasis, innocence-guilt feeling. It can be used on both the sexes from age group 17 to 60 years. Norms are available in form of Mean \& S.D. and Stenine Norms.

1. Self-esteem-self inferiority,

2. Happiness -depression,

3. Calmness - anxiety,

4. Naturality obsessiveness,

5. Independence -dependence,

6. $\quad$ Feeling of being healthy- Hypochondria

7. $\quad$ Innocence-guilt feeling.

\section{Life Satisfaction Scale,}

The questionnaire developed by Q G Alam\& R Shrivastva. It contains 69 Yes/No type items which yield a total score covering six areas — health, personal, economic, marital, social and job. Standardized on 875 adults aging between 18 to 40 years
1. Health Satisfaction
2. Personal Satisfaction
3. Economic Satisfaction
4. Marital Satisfaction
5. Social Satisfaction
6. Job Satisfaction 


\section{A Relationship among Adjustment, Life Style and Life Satisfaction of Educated Unemployed Youth}

\section{Life style Scale}

Life Style Scale developed by S. K. Bawa and S. Kaur, the scale consists 60 items into 6 Dimension like

1. Health Conscious Life Style,

2. Academic Oriented Life Style,

3. Career Oriented Life Style,

4. Socially Oriented Life Style,

5. Trend Seeking Life Style,

6. Family Oriented Life Style.

\section{Procedure of Data Collection}

Data collection is a term used to describe a process of preparing and collecting data - for example as part of a process improvement or similar project. The purpose of data collection is to obtain information to keep on record, to make decisions about important issues, to pass information on to others. Primarily, data is collected to provide information regarding a specific topic.

The researcher was collected data from the Vadodara, Ahmadabad, Anand cities of Gujarat state. Data was collected from the Employment Exchange, face to face meet to the subject, NGO, recruitment fair, ITI Job Fair, etc. Places. For these researches 480 youths of above mention cities were chosen, whose age between 18 years to 40 years was taken and the sample was randomly selected, which are educated unemployed. The data was collected personally. The sample was drawn from three categories. 1:- Male \& Female, 2:- Urban and Rural Area and, 3:Age differences Among Unemployed.

\section{Research Design}

2X2X3 Factorial Designs

\begin{tabular}{|c|c|c|c|c|c|c|}
\hline \multirow{2}{*}{\multicolumn{2}{|c|}{$\begin{array}{l}\text { Gender } \\
\text { Live In Area }\end{array}$}} & \multicolumn{2}{|l|}{ Male } & \multicolumn{2}{|c|}{ Female } & \multirow{2}{*}{ Total } \\
\hline & & Urban & Rural & Urban & Rural & \\
\hline \multirow{3}{*}{ Age } & 18 to 25 Year & 40 & 40 & 40 & 40 & 160 \\
\hline & 26 to 33 Year & 40 & 40 & 40 & 40 & 160 \\
\hline & 34 And Above Year & 40 & 40 & 40 & 40 & 160 \\
\hline \multicolumn{2}{|c|}{ Total } & 120 & 120 & 120 & 120 & 480 \\
\hline
\end{tabular}

\section{Statistical analysis}

The Obtained data of 480 subjects were analysed with adequate statistical methods of ANOVA, And in order to examine significant differences between two specific mean of sub groups of variable the result obtained through such statistical analysis have been presented in details in the main body of the thesis. Qualitative Analysis: - which included descriptive statistics, frequency distribution, and ratio analysis of the response given by the sample. 
A Relationship among Adjustment, Life Style and Life Satisfaction of Educated Unemployed Youth

RESULT AND DISCUSSION OF CORRELATION ADJUSTMENT, LIFE STYLE AND LIFE SATISFACTION

\begin{tabular}{|l|l|l|l|l|}
\hline Correlations of Adjustment, Life Satisfaction and Life Style & \multirow{2}{*}{ Factors } \\
\hline \multirow{4}{*}{ Factors } & Adjustment & $\begin{array}{l}\text { Life } \\
\text { Satisfaction }\end{array}$ & Lifestyle & \\
\hline \multirow{4}{*}{ Life Satisfaction } & Pearson Correlation & 1 & & \\
\cline { 2 - 5 } & Sig. (2-tailed) & & & \\
\cline { 2 - 5 } & $\mathrm{N}$ & 480 & 1 & \\
\hline \multirow{4}{*}{ Lifestyle } & Pearson Correlation & -.015 & & \\
\hline & Sig. (2-tailed) & .747 & 475 & \\
\hline & $\mathrm{N}$ & 475 & $.419^{* *}$ & \\
\hline \multirow{2}{*}{$* *$ Correlation is Significant at the 0.01 level (2-tailed). } & .000 & 480 \\
\hline
\end{tabular}

There is Negative Significant Correlation between Adjustment and Life Satisfaction, (r=-0.015, $\mathrm{P}>0.01$ ) which indicate that adjustment level of unemployed people is not affected life satisfaction. This is Negative Significant at 0.747 it is Indicate that there is no relationship between Adjustment and life satisfaction of educated unemployed youth. Educated unemployed people can adjustment and satisfied with their life.

There is Negative Significant Correlation between Adjustment and Life Style, $(r=-0.147, \mathrm{P}>0.01)$ which indicate that adjustment level of unemployed people is affected their life style. This is Negative Significant at 0.01 it is Indicate that there is no relationship between Adjustment and life style of educated unemployed youth. Educated unemployed people can adjustment with their life. Life Style is Negatively Change and Adjustment with the people is also doesn't change due to unemployment.

There is Positive Correlation between Life Satisfaction and Life Style, ( $\mathrm{r}=-0.419, \mathrm{P}>0.00)$ which indicate that Life Satisfaction level of unemployed people is affected their life style of Unemployed people. This is Positive Significant at 0.00 it is Indicate that there is relationship between Life Satisfaction and life style of educated unemployed youth. Educated unemployed people can't satisfy with their life. Life Style is Change and Life Satisfaction with the people is also change due to unemployment. 
A Relationship among Adjustment, Life Style and Life Satisfaction of Educated Unemployed Youth

RESULT AND DISCUSSION OF CORRELATION COMPONENTS OF ADJUSTMENT

\begin{tabular}{|c|c|c|c|c|c|c|c|}
\hline \multicolumn{8}{|c|}{ Correlations of Adjustment Components } \\
\hline $\begin{array}{l}\text { T1 } \\
\stackrel{2}{2}\end{array}$ & 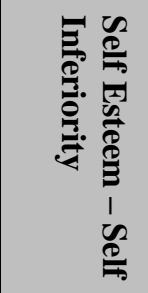 & 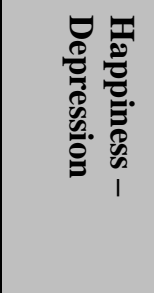 & 吝. & 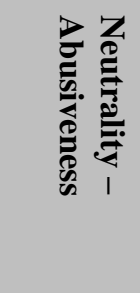 & 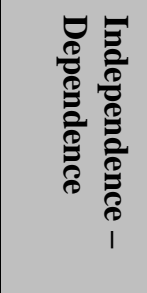 & 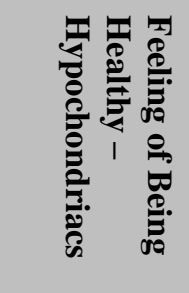 & 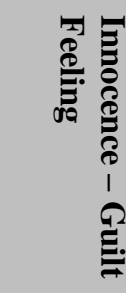 \\
\hline $\begin{array}{l}\text { Self Esteem- } \\
\text { Self Inferiority }\end{array}$ & 1 & & & & & & \\
\hline $\begin{array}{l}\text { Happiness } \\
\text { Depression }\end{array}$ & $.487^{* *}$ & 1 & & & & & \\
\hline $\begin{array}{ll}\text { Calmness } & - \\
\text { Anxiety } & \end{array}$ & $.436^{* *}$ & $.506^{* *}$ & 1 & & & & \\
\hline $\begin{array}{l}\text { Naturality - } \\
\text { Obessiveness }\end{array}$ & $.167^{* *}$ & $.197^{* *}$ & $.225^{* *}$ & 1 & & & \\
\hline $\begin{array}{l}\text { Independence } \\
\text { - Dependence }\end{array}$ & $.354^{* *}$ & $.345^{* *}$ & $.329^{* *}$ & $.263^{* *}$ & 1 & & \\
\hline $\begin{array}{l}\text { Feeling of } \\
\text { Being Healthy } \\
- \\
\text { Hypocondriasis }\end{array}$ & $.449^{* *}$ & $.494^{* *}$ & $.580^{* *}$ & $.181^{* *}$ & $.393^{* *}$ & 1 & \\
\hline $\begin{array}{l}\text { Innocence } \\
\text { Guilt Feeling }\end{array}$ & $.515^{* *}$ & $.440^{* *}$ & $.547^{* *}$ & $.125^{* *}$ & $.370^{* *}$ & $.539^{* *}$ & 1 \\
\hline
\end{tabular}

There is Positive Significant Correlation between Self Esteem - Self Inferiority and Happiness Depression, ( $r=0.487, \mathrm{P}>0.01)$ which indicate that Self Esteem - Self Inferiority of unemployed people is affected their Happiness - Depression. It means when the person is unemployed than his/her self -Inferiority and depression is increase but at the same time if he/she is employed than his/her Self Esteem and happiness is increase. It is clearly shown that status of employment is affect Self Esteem - Self Inferiority and Happiness - Depression.

There is Positive Significant Correlation between Self Esteem - Self Inferiority and Calmness Anxiety, ( $\mathrm{r}=0.436, \mathrm{P}>0.01)$ which indicate that Self Esteem - Self Inferiority of unemployed people is affected their Calmness - Anxiety. It means when the person is unemployed than his/her self -Inferiority and Anxiety is increase but at the same time if he/she is employed than his/her Self Esteem and calmness is increase. It is clearly indicated that status of employment is affect Self Esteem - Self Inferiority and Calmness - Anxiety. 


\section{A Relationship among Adjustment, Life Style and Life Satisfaction of Educated Unemployed Youth}

There is Positive Significant Correlation between Happiness - Depression and Calmness Anxiety, ( $\mathrm{r}=0.506, \mathrm{P}>0.01)$ which indicate that Happiness - Depression of unemployed people is affected their Calmness - Anxiety. It means when the person is unemployed than his/her Depression and Anxiety is increase but at the same time if he/she is employed than his/her Happiness and calmness is increase. It is clearly indicated that status of employment is affect Happiness - Depression and Calmness - Anxiety.

There is Positive Significant Correlation between Self Esteem - Self Inferiority and Naturality Obessiveness, ( $\mathrm{r}=0.167, \mathrm{P}>0.01)$ which indicate that Self Esteem - Self Inferiority of unemployed people is affected their Naturality - Obessiveness. It means when the person is unemployed than his/her self-Inferiority and Obessiveness is increase but at the same time if he/she is employed than his/her Self Esteem and Naturality is increase. It is clearly indicated that status of employment is affect Self Esteem - Self Inferiority and Naturality - Obessiveness.

There is Positive Significant Correlation between Happiness - Depression and Naturality Obessiveness, ( $\mathrm{r}=0.197, \mathrm{P}>0.01)$ which indicate that Self Esteem - Self Inferiority of unemployed people is affected their Happiness - Depression. It means when the person is unemployed than his/her Depression and Obessiveness is increase but at the same time if he/she is employed than his/her Happiness and Naturality is increase. It is clearly indicated that status of employment is affect Happiness - Depression and Naturality - Obessiveness.

There is Positive Significant Correlation between Calmness - Anxiety and Naturality Obessiveness, $(\mathrm{r}=0.225, \mathrm{P}>0.01)$ which indicate that Calmness - Anxiety of unemployed people is affected their Naturality - Obessiveness. It means when the person is unemployed than his/her Anxiety and Obessiveness is increase but at the same time if he/she is employed than his/her Calmness and Obessiveness is increase. It is clearly indicated that status of employment is affect Calmness - Anxiety and Naturality - Obessiveness.

There is Positive Significant Correlation between Self Esteem - Self Inferiority and Independence - Dependence, $(\mathrm{r}=0.354, \mathrm{P}>0.01)$ which indicate that Self Esteem - Self Inferiority of unemployed people is affected their Independence - Dependence. It means when the person is unemployed than his/her Self Inferiority and Dependence is increase but at the same time if he/she is employed than his/her Self Esteem - Independence is increase. It is clearly indicated that status of employment is affect Self Esteem - Self Inferiority and Independence Dependence.

There is Positive Significant Correlation between Happiness - Depression and Independence Dependence, $(\mathrm{r}=0.345, \mathrm{P}>0.01)$ which indicate that Happiness - Depression of unemployed people is affected their Independence - Dependence. It means when the person is unemployed than his/her Depression and Dependence is increase but at the same time if he/she is employed

(C) The International Journal of Indian Psychology, ISSN 2348-5396 (e) | ISSN: 2349-3429 (p) | 156 


\section{A Relationship among Adjustment, Life Style and Life Satisfaction of Educated Unemployed Youth}

than his/her Happiness - Independence is increase. It is clearly indicated that status of employment is affect Happiness - Depression and Independence - Dependence.

There is Positive Significant Correlation between Calmness - Anxiety and Independence Dependence, $(\mathrm{r}=0.329, \mathrm{P}>0.01)$ which indicate that Calmness - Anxiety of unemployed people is affected their Independence - Dependence. It means when the person is unemployed than his/her Anxiety and Dependence is increase but at the same time if he/she is employed than his/her Calmness - Independence is increase. It is clearly indicated that status of employment is affect Calmness - Anxiety and Independence - Dependence.

There is Positive Significant Correlation between Naturality - Obessiveness and Independence Dependence, $(\mathrm{r}=0.263, \mathrm{P}>0.01)$ which indicate that Naturality - Obessiveness of unemployed people is affected their Independence - Dependence. It means when the person is unemployed than his/her Obessiveness and Dependence is increase but at the same time if he/she is employed than his/her Naturality- Independence is increase. It is clearly indicated that status of employment is affect Naturality - Obessiveness and Independence - Dependence.

There is Positive Significant Correlation between Self Esteem - Self Inferiority and Feeling of Being Healthy - Hypocondriasis, $(\mathrm{r}=0.449, \mathrm{P}>0.01)$ which indicate that Self Esteem - Self Inferiority of unemployed people is affected their Feeling of Being Healthy - Hypocondriasis. It means when the person is unemployed than his/her Self Inferiority and Hypocondriasis is increase but at the same time if he/she is employed than his/her Self Esteem- Feeling of Being Healthy is increase. It is clearly indicated that employment status is affect Self Esteem - Self Inferiority and Feeling of Being Healthy - Hypocondriasis.

There is Positive Significant Correlation between Happiness - Depression and Feeling of Being Healthy - Hypocondriasis, $(\mathrm{r}=0.494, \mathrm{P}>0.01)$ which indicate that Happiness - Depression of unemployed people is affected their Feeling of Being Healthy - Hypocondriasis. It means when the person is unemployed than his/her Depression and Hypocondriasis is increase but at the same time if he/she is employed than his/her Happiness- Feeling of Being Healthy is increase. It is clearly indicated that status of employment is affect Happiness - Depression and Feeling of Being Healthy - Hypocondriasis.

There is Positive Significant Correlation between Calmness - Anxiety and Feeling of Being Healthy - Hypocondriasis, $(\mathrm{r}=0.580, \mathrm{P}>0.01)$ which indicate that Calmness - Anxiety of unemployed people is affected their Feeling of Being Healthy - Hypocondriasis. It means when the person is unemployed than his/her Anxiety and Hypocondriasis is increase but at the same time if he/she is employed than his/her Calmness - Feeling of Being Healthy is increase. It is clearly indicated that status of employment is affect Calmness - Anxiety and Feeling of Being Healthy - Hypocondriasis. 


\section{A Relationship among Adjustment, Life Style and Life Satisfaction of Educated Unemployed Youth}

There is Positive Significant Correlation between Naturality - Obessiveness and Feeling of Being Healthy - Hypocondriasis, $(\mathrm{r}=0.181, \mathrm{P}>0.01)$ which indicate that Naturality Obessiveness of unemployed people is affected their Feeling of Being Healthy - Hypocondriasis. It means when the person is unemployed than his/her Obessiveness and Hypocondriasis is increase but at the same time if he/she is employed than his/her Naturality- Feeling of Being Healthy is increase. It is clearly indicated that status of employment is affect Naturality Obessiveness and Feeling of Being Healthy - Hypocondriasis.

There is Positive Significant Correlation between Independence - Dependence and Feeling of Being Healthy - Hypocondriasis, $(\mathrm{r}=0.393, \mathrm{P}>0.01)$ which indicate that Independence Dependence of unemployed people is affected their Feeling of Being Healthy - Hypocondriasis. It means when the person is unemployed than his/her Dependence Obessiveness and Hypocondriasis is increase but at the same time if he/she is employed than his/her Independence- Feeling of Being Healthy is increase. It is clearly indicated that status of employment is affect Independence - Dependence and Feeling of Being Healthy Hypocondriasis.

There is Positive Significant Correlation between Self Esteem - Self Inferiority and Innocence Guilt Feeling, ( $\mathrm{r}=0.515, \mathrm{P}>0.01)$ which indicate that Self Esteem - Self Inferiority of unemployed people is affected their Innocence - Guilt Feeling. It means when the person is unemployed than his/her Self Inferiority and Guilt Feeling is increase but at the same time if he/she is employed than his/her Self Esteem - Innocence is increase. It is clearly indicated that status of employment is affect Self Esteem - Self Inferiority and Innocence - Guilt Feeling.

There is Positive Significant Correlation between Happiness - Depression and Innocence - Guilt Feeling, $(\mathrm{r}=0.440, \mathrm{P}>0.01)$ which indicate that Happiness - Depression of unemployed people is affected their Innocence - Guilt Feeling. It means when the person is unemployed than his/her Depression and Guilt Feeling is increase but at the same time if he/she is employed than his/her Happiness - Innocence is increase. It is clearly indicated that status of employment is affect Happiness - Depression and Innocence - Guilt Feeling.

There is Positive Significant Correlation between Calmness - Anxiety and Innocence - Guilt Feeling, ( $r=0.547, \mathrm{P}>0.01)$ which indicate that Calmness - Anxiety of unemployed people is affected their Innocence - Guilt Feeling. It means when the person is unemployed than his/her Anxiety and Guilt Feeling is increase but at the same time if he/she is employed than his/her Calmness - Innocence is increase. It is clearly indicated that status of employment is affect Calmness - Anxiety and Innocence - Guilt Feeling.

There is Positive Significant Correlation between Naturality - Obessiveness and Innocence Guilt Feeling, ( $\mathrm{r}=0.125, \mathrm{P}>0.01)$ which indicate that Naturality - Obessiveness of unemployed 


\section{A Relationship among Adjustment, Life Style and Life Satisfaction of Educated Unemployed Youth}

people is affected their Innocence - Guilt Feeling. It means when the person is unemployed than his/her Obessiveness and Guilt Feeling is increase but at the same time if he/she is employed than his/her Naturality - Innocence is increase. It is clearly indicated that status of employment is affect Naturality - Obessiveness and Innocence - Guilt Feeling.

There is Positive Significant Correlation between Independence - Dependence and Innocence Guilt Feeling, ( $r=0.370, \mathrm{P}>0.01$ ) which indicate that Independence - Dependence of unemployed people is affected their Innocence - Guilt Feeling. It means when the person is unemployed than his/her Dependence and Guilt Feeling is increase but at the same time if he/she is employed than his/her Independence - Innocence is increase. It is clearly indicated that status of employment is affect Independence - Dependence and Innocence - Guilt Feeling.

There is Positive Significant Correlation between Feeling of Being Healthy - Hypocondriasis and Innocence - Guilt Feeling, $(r=0.539, \mathrm{P}>0.01)$ which indicate that Feeling of Being Healthy Hypocondriasis of unemployed people is affected their Innocence - Guilt Feeling. It means when the person is unemployed than his/her Hypocondriasis and Guilt Feeling is increase but at the same time if he/she is employed than his/her Feeling of Being Healthy - Innocence is increase. It is clearly indicated that status of employment is affect Feeling of Being Healthy Hypocondriasis and Innocence - Guilt Feeling.

\begin{tabular}{|c|c|c|c|c|c|c|c|}
\hline \multicolumn{5}{|c|}{ Result and Discussion of Correlation Components of Life Style } & Correlations & & \\
\hline Factors & $\begin{array}{l}\text { Health } \\
\text { Conscious } \\
\text { Life Style }\end{array}$ & $\begin{array}{l}\text { Academic } \\
\text { Oriented } \\
\text { Life Style }\end{array}$ & $\begin{array}{l}\text { Career } \\
\text { Oriented } \\
\text { Life } \\
\text { Style }\end{array}$ & $\begin{array}{l}\text { Socially } \\
\text { Oriented } \\
\text { Life Style }\end{array}$ & $\begin{array}{l}\text { Family } \\
\text { Oriented } \\
\text { Life Style }\end{array}$ & $\begin{array}{l}\text { Trend } \\
\text { Seeking } \\
\text { Life } \\
\text { Style }\end{array}$ & $\begin{array}{l}\text { Life } \\
\text { Style }\end{array}$ \\
\hline $\begin{array}{l}\text { Health } \\
\text { Conscious Life } \\
\text { Style }\end{array}$ & 1 & & & & & & \\
\hline $\begin{array}{l}\text { Academic } \\
\text { Oriented Life } \\
\text { Style }\end{array}$ & $.699^{* *}$ & 1 & & & & & \\
\hline $\begin{array}{l}\text { Career } \\
\text { Oriented Life } \\
\text { Style }\end{array}$ & $.533^{* *}$ & $.634^{* *}$ & 1 & & & & \\
\hline $\begin{array}{l}\text { Socially } \\
\text { Oriented Life } \\
\text { Style }\end{array}$ & $.564^{* *}$ & $.577^{* *}$ & $.601^{* *}$ & 1 & & & \\
\hline $\begin{array}{l}\text { Family } \\
\text { Oriented Life } \\
\text { Style }\end{array}$ & $.096^{*}$ & $.191^{* *}$ & $.172^{* *}$ & $.194^{* *}$ & 1 & & \\
\hline $\begin{array}{l}\text { Trend Seeking } \\
\text { Life Style }\end{array}$ & $.524^{* *}$ & $.460^{* *}$ & $.439^{* *}$ & $.499^{* *}$ & -.022 & 1 & \\
\hline
\end{tabular}

(c) The International Journal of Indian Psychology, ISSN 2348-5396 (e) | ISSN: 2349-3429 (p) | 159 


\section{A Relationship among Adjustment, Life Style and Life Satisfaction of Educated Unemployed Youth}

There is Positive Significant Correlation between Health Conscious Life Style and Academic Oriented Life Style, $(\mathrm{r}=0.699, \mathrm{P}>0.01)$ which indicate that Health Conscious Life Style of unemployed people is affected their Academic Oriented Life Style. It means when the person is unemployed than he/she is not care about Health and this impact on his/her Academic Oriented Life Style. It is clearly indicated that employment status disturbs Health and Academic Oriented Life Style.

There is Positive Significant Correlation between Health Conscious Life Style and Career Oriented Life Style, ( $r=0.533$, P $>0.01)$ which indicate that Health Conscious Life Style of unemployed people is affected their Career Oriented Life Style. It means when the person is unemployed than he/she is not care about Health and this impact on his/her career Oriented Life Style. It is clearly indicated that employment status disturbs Health and Career Oriented Life Style.

There is Positive Significant Correlation between Academic Oriented Life Style and Career Oriented Life Style, $(\mathrm{r}=0.634, \mathrm{P}>0.01)$ which indicate that Academic Oriented Life Style of unemployed people is affected their Career Oriented Life Style. It means when the person is unemployed than he/she is not care about Academic and this impact on his/her career Oriented Life Style. It is clearly indicated that employment status disturbs Academic and Career Oriented Life Style.

There is Positive Significant Correlation between Health Conscious Life Style and Socially Oriented Life Style, $(\mathrm{r}=0.564, \mathrm{P}>0.01)$ which indicate that Health Conscious Life Style of unemployed people is affected their Social Oriented Life Style. It means when the person is unemployed than he/she is not care about Health and this impact on his/her Social Oriented Life Style. It is clearly indicated that employment status disturbs Health and Social Oriented Life Style.

There is Positive Significant Correlation between Academic Oriented Life Style and Socially Oriented Life Style, $(\mathrm{r}=0.577, \mathrm{P}>0.01)$ which indicate that Academic Oriented Life Style of unemployed people is affected their Social Oriented Life Style. It means when the person is unemployed than he/she is not care about Academic and this impact on his/her Social Oriented Life Style. It is clearly indicated that employment status disturbs Academic and Social Oriented Life Style.

There is Positive Significant Correlation between Career Oriented Life Style and Socially Oriented Life Style, $(\mathrm{r}=0.601, \mathrm{P}>0.01)$ which indicate that Career Oriented Life Style of unemployed people is affected their Social Oriented Life Style. It means when the person is unemployed than he/she is not care about Career and this impact on his/her Social Oriented Life 


\section{A Relationship among Adjustment, Life Style and Life Satisfaction of Educated Unemployed Youth}

Style. It is clearly indicated that employment status disturbs Career and Social Oriented Life Style.

There is Positive Significant Correlation between Health Conscious Life Style and Family Oriented Life Style, $(\mathrm{r}=0.096, \mathrm{P}>0.01)$ which indicate that Health Conscious Life Style of unemployed people is affected their Family Oriented Life Style. It means when the person is unemployed than he/she is not care about Health and this impact on his/her Family Oriented Life Style. It is clearly indicated that employment status disturbs Health Conscious Life Style and Family Oriented Life Style.

There is Positive Significant Correlation between Academic Oriented Life Style and Family Oriented Life Style, $(\mathrm{r}=0.191, \mathrm{P}>0.01)$ which indicate that Academic Oriented Life Style of unemployed people is affected their Family Oriented Life Style. It means when the person is unemployed than he/she is not care about Academic and this impact on his/her Family Oriented Life Style. It is clearly indicated that employment status disturbs Academic and Family Oriented Life Style.

There is Positive Significant Correlation between Career Oriented Life Style and Family Oriented Life Style, $(\mathrm{r}=0.172, \mathrm{P}>0.01)$ which indicate that Career Oriented Life Style of unemployed people is affected their Family Oriented Life Style. It means when the person is unemployed than he/she is not care about Career and this impact on his/her Family Oriented Life Style. It is clearly indicated that employment status disturbs Career and Family Oriented Life Style.

There is Positive Significant Correlation between Socially Oriented Life Style and Family Oriented Life Style, $(\mathrm{r}=0.194, \mathrm{P}>0.01)$ which indicate that Socially Oriented Life Style of unemployed people is affected their Family Oriented Life Style. It means when the person is unemployed than he/she is not care about socially and this impact on his/her Family Oriented Life Style. It is clearly indicated that employment status disturbs Socially Oriented Life Style and Family Oriented Life Style.

There is Positive Significant Correlation between Health Conscious Life Style and Trend Seeking Life Style, $(r=0.524, \mathrm{P}>0.01)$ which indicate that Health Conscious Life Style of unemployed people is affected their Trend Seeking Life Style. It means when the person is unemployed than he/she is not care about Health and this impact on his/her Trend Seeking Life Style. It is clearly indicated that employment status disturbs Health Conscious Life Style and Trend Seeking Life Style.

There is Positive Significant Correlation between Academic Oriented Life Style and Trend Seeking Life Style, $(\mathrm{r}=0.460, \mathrm{P}>0.01)$ which indicate that Academic Oriented Life Style of 


\section{A Relationship among Adjustment, Life Style and Life Satisfaction of Educated Unemployed Youth}

unemployed people is affected their Trend Seeking Life Style. It means when the person is unemployed than he/she is not care about Academic and this impact on his/her Trend Seeking Life Style. It is clearly indicated that employment status disturbs Academic Oriented Life Style and Trend Seeking Life Style.

There is Positive Significant Correlation between Career Oriented Life Style and Trend Seeking Life Style, $(r=0.439, \mathrm{P}>0.01)$ which indicate that Career Oriented Life Style of unemployed people is affected their Trend Seeking Life Style. It means when the person is unemployed than he/she is not care about Career and this impact on his/her Trend Seeking Life Style. It is clearly indicated that employment status disturbs Career and Trend Seeking Life Style.

There is Positive Significant Correlation between Socially Oriented Life Style and Trend Seeking Life Style, $(\mathrm{r}=0.499, \mathrm{P}>0.01)$ which indicate that Socially Oriented Life Style of unemployed people is affected their Trend Seeking Life Style. It means when the person is unemployed than he/she is not care about socially and this impact on his/her Trend Seeking Life Style. It is clearly indicated that employment status disturbs socially and Trend Seeking Life Style.

There is Negative Significant Correlation between Family Oriented Life Style and Trend Seeking Life Style, $(r=-0.022, \mathrm{P}>0.01$ ) which indicate that Family Oriented Life Style of unemployed people is Not affected their Trend Seeking Life Style. It means when the person is unemployed than he/she is care about Family and this impact on his/her Trend Seeking Life Style. It is clearly indicated that employment status don't disturbs Family Oriented Life Style and Trend Seeking Life Style.

RESULT AND DISCUSSION OF CORRELATION COMPONENTS OF LIFE SATISFACTION

\begin{tabular}{|l|l|l|l|l|l|}
\hline Correlations of Life Satisfaction Components \\
\hline Factor & $\begin{array}{l}\text { Health } \\
\text { Satisfaction }\end{array}$ & $\begin{array}{l}\text { Personal } \\
\text { Satisfaction }\end{array}$ & $\begin{array}{l}\text { Economical } \\
\text { Satisfaction }\end{array}$ & $\begin{array}{l}\text { Marital } \\
\text { Satisfaction }\end{array}$ & $\begin{array}{l}\text { Social } \\
\text { Satisfaction }\end{array}$ \\
\hline Health Satisfaction: & 1 & & & & \\
\hline Personal Satisfaction & $.158^{* *}$ & 1 & & & \\
\hline $\begin{array}{l}\text { Economical } \\
\text { Satisfaction }\end{array}$ & $.173^{* *}$ & $-.092^{*}$ & 1 & & \\
\hline Marital Satisfaction & $.124^{* *}$ & 0.085 & 0.075 & 1 & \\
\hline Social Satisfaction & $.320^{* *}$ & $.229^{* *}$ & -0.028 & 0.025 & 1 \\
\hline$* *$ Correlation is significant at the 0.01 level (2-tailed). & \\
\hline$*$. Correlation is significant at the 0.05 level (2-tailed). \\
\hline
\end{tabular}

(C) The International Journal of Indian Psychology, ISSN 2348-5396 (e) | ISSN: 2349-3429 (p) | 162 


\section{A Relationship among Adjustment, Life Style and Life Satisfaction of Educated Unemployed Youth}

There is Positive Significant Correlation between Health Satisfaction and Personal Satisfaction, $(\mathrm{r}=0.158, \mathrm{P}>0.01)$ which indicate that Health Satisfaction of unemployed people is affected their Personal Satisfaction. It means when the person is unemployed than he/she is not care about Health and this impact on his/her Personal Satisfaction. It is clearly indicated that employment status disturbs Health and Personal Satisfaction.

There is Positive Significant Correlation between Health Satisfaction and Economical Satisfaction, $(r=0.173, \mathrm{P}>0.01)$ which indicate that Health Satisfaction of unemployed people is affected their Economical Satisfaction. It means when the person is unemployed than he/she is not care about Health and this impact on his/her Economical Satisfaction. It is clearly indicated that employment status disturbs Health and Economical Satisfaction.

There is Negative Significant Correlation between Personal Satisfaction and Economical Satisfaction, $(\mathrm{r}=-0.092$, $\mathrm{P}>0.01$ ) which indicate that Personal Satisfaction of unemployed people is don't affected their Economical Satisfaction. It means when the person is unemployed than he/she is care about Personal and this doesn't impact on his/her Economical Satisfaction. It is clearly indicated that employment status doesn't disturbs Personal and Economical Satisfaction.

There is Positive Significant Correlation between Health Satisfaction and Marital Satisfaction, $(\mathrm{r}=0.124, \mathrm{P}>0.01)$ which indicate that Health Satisfaction of unemployed people is affected their Marital Satisfaction. It means when the person is unemployed than he/she is not care about Heath and this impact on his/her Marital Satisfaction. It is clearly indicated that employment status disturbs Health and Marital Satisfaction.

There is Positive Significant Correlation between Personal Satisfaction and Marital Satisfaction, $(\mathrm{r}=0.085, \mathrm{P}>0.01)$ which indicate that Personal Satisfaction of unemployed people is affected their Marital Satisfaction. It means when the person is unemployed than he/she is not care about Personal and this impact on his/her Marital Satisfaction. It is clearly indicated that employment status disturbs Personal and Marital Satisfaction.

There is Positive Significant Correlation between Economical Satisfaction and Marital Satisfaction, $(r=0.075, \mathrm{P}>0.01)$ which indicate that Economical Satisfaction of unemployed people is affected their Marital Satisfaction. It means when the person is unemployed than he/she is not care about Economical and this impact on his/her Marital Satisfaction. It is clearly indicated that employment status disturbs Economical and Marital Satisfaction.

There is Positive Significant Correlation between Health Satisfaction and Social Satisfaction, $(\mathrm{r}=0.320, \mathrm{P}>0.01)$ which indicate that Health Satisfaction of unemployed people is affected their Social Satisfaction. It means when the person is unemployed than he/she is not care about Heath 


\section{A Relationship among Adjustment, Life Style and Life Satisfaction of Educated Unemployed Youth}

and this impact on his/her Social Satisfaction. It is clearly indicated that employment status disturbs Health and Social Satisfaction.

There is Positive Significant Correlation between Personal Satisfaction and Social Satisfaction, $(\mathrm{r}=0.229, \mathrm{P}>0.01$ ) which indicate that Personal Satisfaction of unemployed people is affected their Social Satisfaction. It means when the person is unemployed than he/she is not care about Personal and this impact on his/her Social Satisfaction. It is clearly indicated that employment status disturbs Personal and Social Satisfaction.

There is Negative Significant Correlation between Economical Satisfaction and Social Satisfaction, $(r=-0.028, \mathrm{P}>0.01)$ which indicate that Economical Satisfaction of unemployed people is don't affected their Social Satisfaction. It means when the person is unemployed than he/she is care about Economical and this impact on his/her Social Satisfaction. It is clearly indicated that employment status doesn't disturbs Economic and Social Satisfaction.

There is Positive Significant Correlation between Marital Satisfaction and Social Satisfaction, $(\mathrm{r}=0.025, \mathrm{P}>0.01)$ which indicate that Marital Satisfaction of unemployed people is affected their Social Satisfaction. It means when the person is unemployed than he/she is not care about Marital Life and this impact on his/her Social Satisfaction. It is clearly indicated that employment status disturbs Marital and Social Satisfaction.

\section{CONCLUSION}

Summary and conclusion is very important in any research report of any study. But in the whole study, the last chapter is the most important part. The summary of the study is helpful in studying of the research, a very important in the short time of the research value of researcher. It is a tradition that a short glimpse of beginning to end is given in report of the study. Thus, this chapter is as important as other chapters.

\section{Correlation of Adjustment, Life Style and Life Satisfaction}

There is Negative Correlation Found between Adjustment and Life Satisfaction of Educated Unemployed People. It is indicate that adjustment level of unemployed people is not affected life satisfaction. Educated unemployed people can adjustment and satisfied with their life.

There is Negative Correlation Found between Adjustment and Life Style of Educated Unemployed People. It indicates that adjustment level of unemployed people doesn't affect their life style. Life Style is Negatively Change and Adjustment with the people also doesn't change due to unemployment. 


\section{A Relationship among Adjustment, Life Style and Life Satisfaction of Educated Unemployed Youth}

There is Positive Correlation between Life Satisfaction and Life Style of Educated Unemployed People. Life Style is Change and Life Satisfaction with the people is also change due to unemployment.

\section{SUGGESTION}

As far as the present study is concerned, the findings have been summarized as above, with all the limitations of time, tools and sample available. The researcher admits that, much can be improved and still more can be added. However, instead of going in to ideal conditions and allround improvements, the investigator would restrict him to the few suggestions for follow-up work.

1. The Study Can Be conducted from the point of view of Caste, Religious and etc. of Variable with Gender, Live in Area and Ages.

2. The Study Can Be conduct According to the Family Income and social economic status wise with above Variable with Gender, Live in Area and Ages.

3. The Study Can Be conducted from the point of view of social status and prestige of family wise with above Variable with Gender, Live in Area and Ages.

4. The Study Can Be conducted from the point of view of Educational Qualification with above Variable with Gender, Live in Area and Ages.

5. The Study Can Be conducted from the point of view of Marital Status with above Variable with Gender, Live in Area and Ages.

6. The Study Can Be conducted from the point of view of Time Duration of Unemployment with above Variable of Gender, Live in Area and Ages.

7. The Study Can Be conducted from the point of view of Monthly Income and Family Expenditure in Month wise with above Variable of Gender, Live in Area and Ages.

\section{LIMITATION OF THE STUDY}

The abroad aim of any research is to make generalizations from the findings related to the sample and to apply these generalizations to the population or universe from which the sample is randomly drawn. This requires computation of parameters with appropriate statistical techniques. However, such aim of generalization in any research work has its own limitations by the statistics used and the procedure for selection of sample as well as sampling errors. For the present research the researcher has taken all the possible care and precautions to make most adequate statistical analysis and most representatives 'selection of sample through randomization. Any way still at the same time the investigator is fully conscious of the limitations of the study, they are as under:

1. Part time job working people was not included.

2. All age was taken as sample between 20 to 40 years.

3. Data Analysis was done by analysis of variance and correlation only.

4. Only Vadodara, Anand and Ahmedabad cities included for this research. 


\section{A Relationship among Adjustment, Life Style and Life Satisfaction of Educated Unemployed Youth}

5. In Present Research Monthly Income and Family Expenditure was not considered as independent variable.

6. Sample of the present research was not so large so result of the study research cannot be generalized.

7. The Study was not considered as point of view of Caste, Religious and etc. of Variable with Gender, Live in Area and Ages.

8. The Study was not considered as point of view of Time Duration of Unemployment with above Variable of Gender, Live in Area and Ages.

9. To reach conclusive decision, the study may be reported with a few more aspects.

10. The Study was not considered as point of view of, Family Income and social economic status, Educational Qualification and Family Social Status and Prestige of Family wise with above Variable with Gender, Live in Area and Ages.

11. The sample is selected from available Unemployment Centre and Interview Held in the industry.

\section{IMPLICATION OF THE RESEARCH}

After the completed research every researcher found something in the study. This findings help to society or particular group of the people to improve in person or society. Here in the research researcher found that Significant Differences is existed between Male and Female in Adjustment during the Unemployed Condition, Here the male and female has to try to adjustment in each and every aspect of life during the unemployment condition, so that the restlessness can decrease up to certain level. Further thing are that to be Significant Differences is existed between Urban and Rural People in Adjustment during the Unemployed Condition, as said above in implication that Urban and Rural people get training for getting employment so that the adjustment level with every part life can make possible.

Further implication of the study is that Significant Differences is existed between Male and Female in Life Style during the Unemployed Condition; definitely changes comes in life style during the unemployment but here at least the people has to take care about saving when they are earning or any other family member/s are earning so that when unemployment condition arise the life style can maintain. Further implication of the study is that Significant Differences is existed between Urban and Rural People in Life Style during the Unemployed Condition, in the urban area there are in family member/s or couple mostly in the $21^{\text {st }}$ century both are earning so that the life style can be manage, but in the village there are only male are most of earning so that the expense of the family is not divided in to the family member that why the life style is changes. Further implication of the study is that Significant Differences is found between Types of Gender and Different Ages of People in Life Style during the Unemployed Condition.

Further implication of the study is that Significant Differences is found between Types of Different Ages and different Types of Live in Area people in Life Style during the Unemployed 


\section{A Relationship among Adjustment, Life Style and Life Satisfaction of Educated Unemployed Youth}

Condition. Absolutely in the male and female life style has been change when they are unemployed and same for urban and rural people so that in the Indian concept people must have saving this saving can helpful them in the condition of unemployment. Further implication of the study is that Significant Differences is found between Types of Gender, Types of Different Ages and different Types of Live in Area people in Life Style during the Unemployed Condition; as researcher found in this research people must have an alternative way for earning so that they can survive easily in compare to depend upon only job.

Furthermore to implication of the study is that Significant Differences is existed between Male and Female in Life Satisfaction during the Unemployed Condition. Definitely the life satisfaction level decrease when person are unemployed so that at this time person has to be maintain their personality, aggression level, anxiety level, emotion, isolation from the society, relationship maintain problems etc. so that Life satisfaction level can be uphold. There are an increasing number of young patients visiting psychiatrists for clinical depression caused by unemployment so this situation can be decrease.

Further effect of the study is that Significant Differences is found between Types of gender and different ages of people in Life Satisfaction during the Unemployed Condition. In the male and female there are absolutely the differences come in the life satisfaction level because of employment; when person are unemployed than definitely life satisfaction level decrease, so that people has to earn and save some amount of money which can be used in the unemployment condition, and the level of life satisfaction level can be maintained.

These are some of implication can be maintain and balance in the society so that these Adjustment, Life Style and Life Satisfaction level can be uphold, problems like adjustment, anger, anxiety, depressions, emotional problems, crime rate increasing, mental health problems, stress, suicides, blaming themselves, cardiovascular decease increasing, family support decreasing, isolation etc. can be decreased.

\section{Acknowledgments}

The author appreciates all those who participated in the study and helped to facilitate the research process.

\section{Conflict of Interests}

The author declared no conflict of interests.

\section{REFERENCES}

Arun Kumar Singh (1993). Tests, Measurement and Research Methods in Behavioural Science, 1st reprint 1993, Tata Mc Graw Hill Publishing Company Limited 4/12, Asaf Ali Road New Delhi-110002. 


\section{A Relationship among Adjustment, Life Style and Life Satisfaction of Educated Unemployed Youth}

B. A. Parikh. Industrial Psychology, University Granth Nirman board Ahmadabad Gujarat, India.

C. B. Memoria \& S. V. Ganekar, (2005). Personnel Management, text and cases, 25th edit. 2005, Himalaya publishing house “Ramndoot”, Dr. Bhalerao marg, gorgon, Mumbai-400004.

Cathrynheyman (2016) revisited [10 Sep 2016] cathrynheyman.com/pdfs/Life\%20Satisfaction\%20Survey.pdf

Chest Journal (2016) revisited [10 Sep 2016] chestjournal.chestpubs.org/content/101/1/26.full.pdf

Dr. Garima Gupta \&A N Sinha (2014) “Marital Adjustment and Psychological Well-Being Differences in Working and Non-Working Female” The International Journal of Indian Psychology, Volume: 01, Issue: 03, ISSN 2348-5396, Page No- 61 to 72

Dr. Krishna J. Vaghela (2014) “A Comparative study of Marital Adjustment among Employed and Unemployed Married Women of Urban and Rural Area” The International Journal of Indian Psychology, ISSN 2348-5396, Volume 2, Issue 1, No-3, Oct to Dec 2014, Page No35 to 40

Dr. Manju Khokhar and Dr. Vibha Nagar (2014) “A Comparative study of Mental Health among Employed and Unemployed Young Technical Personnel” The International Journal of Indian Psychology, ISSN 2348-5396, Volume 2, Issue 1, No-02, Oct to Dec 2014, Page No - 13 to 16

Dr. S. M. Makvana (2007) “To Study the Role of Perceived Organizational Health in the Relationship of Work Involvement and Job Satisfaction in Different Organizations” Ph.D. Thesis, Department of Psychology, Sardar Patel University, Vallabh Vidha Nagar, Anand

Dr. S. M. Makvana (2014) "Marital Adjustment among Serving and Non-Serving Married Couples” The International Journal of Indian Psychology: Volume: 01, Issue: 03, ISSN 2348-5396, Page No- 6 to 14

Dr. Shashi Kala Singh (2014) "Life Satisfaction and Stress Level among Working and NonWorking Women” The International Journal of Indian Psychology: Volume: 01, Issue: 04 No.1, ISSN 2348-5396, July-September 2014, Page No - 115 to 122

Hiral Y Suthar and Dr. M. G Mansuri (2016) “Anxiety among Male and Female of High and Low Socio-Economic Status” The International Journal of Indian Psychology, ISSN 23485396 (e), ISSN: 2349-3429 (p) Volume 3, Issue 3, No.2, Page No - 06 to 08

J.P. Guildford (1965). Fundamental Statistics in Psychology and Education, 4th edit. 1965 Mc Graw Hill Books Company, New York.

Jain Ashika and Dr. S. M. Kanji (2015) "Mental Health of Employed and Unemployed People in Ahmedabad” The International Journal of Indian Psychology ISSN 2348-5396, Volume 2, Issue 3, No-1, April to June 2015, Page No-157 to 161

K. Aswathapa (2007). Organizational Behavior, Text and Cases and Games, 7th revised edit. 2007, Himalaya publishing house "Ramndoot”, Dr. Bhalerao marg, gorgon, Mumbai400004. 


\section{A Relationship among Adjustment, Life Style and Life Satisfaction of Educated Unemployed Youth}

Kachchhi Parvati (2014) “Adjustment Problem among working women and non-working women” The International Journal of Indian Psychology: Volume: 01, Issue: 03, ISSN 2348-5396, Page No- 138 to 140

Kiranben Vaghela (2014) "Mental Health of Working and Non-Working Women in Ahmadabad” The International Journal of Indian Psychology, ISSN 2348-5396, Volume 2, Issue 1, Page No- 11 to 16

Kiranben Vaghela (2014) "Mental Health of Working and Non-Working Women in Ahmadabad" The International Journal of Indian Psychology, ISSN 2348-5396, Volume 1, Issue 4, Page No - 53 to 58

Muddanagouda Patil (2016) "Stress Level of Working and Non-Working Women" The International Journal of Indian Psychology, ISSN 2348-5396 (e), ISSN: 2349-3429 (p); Volume 3, Issue 2, No.4, Page No - 32 to 37

Mukesh Bhatt (2009). A Study of Life Satisfaction among Teachers and Engineers. Department of Psychology, Sardar Patel University, V V Nagar, anand Gujarat, India.

P. Subharao (2008). Personnel and Human Resource Management, text \& cases, 2nd edit. 2008, Himalaya publishing house "Ramndoot”, Dr. Bhalerao marg, gorgon, Mumbai-400004.

Psychservices (2016) revisited [10 Sep 2016]

psychservices.psychiatryonline.org/cgi/reprint/61/3/314.pdf

Schultz. P. Duane \& Schultz. Ellen Sydney (2002). Psychology \& Work Today, Sixth Edition, Mac Millan Publishing Company, New York, Pg 271-289.

Shodh Ganga (2016) revisited [10 Sep 2016] from shodhganga.inflibnet.ac.in

Sonalba G Parmar (2014) "Mental Health and Marital Adjustment among Working and NonWorking Women” The International Journal of Indian Psychology: Volume: 01, Issue: 04, ISSN 2348-5396, Page No- 64 to 69

Stephen P Robbins (2008). Organizational Behaviour, 13th edit. 2008 Prentice-hall of India private limited, New Delhi-110001.

Sunil Jadva and Dr. Pankaj Suvera (2014) "The Psychological Wellbeing among Hindu and Muslim Educated Unemployed People” The International Journal of Indian Psychology: Volume: 02, Issue: 02, February 2014, Page No - 01 to 08

Wikipedia (2016) revisited [10 Sep 2016] en.wikipedia.org/wiki/Employment

Yagnik L. R, Dhila B D, Chothani K. B., (2004), Research Methodology Akshar Publication Raipur Ahmadabad.

How to cite this article: R Parmar (2016), A Relationship among Adjustment, Life Style and Life Satisfaction of Educated Unemployed Youth, International Journal of Indian Psychology, Volume 3, Issue 4, No. 77, ISSN:2348-5396 (e), ISSN:2349-3429 (p), DIP:18.01.076/20160304, ISBN: 978-1-365-51571-2 